\title{
Standing Ovation
}

\author{
Michael K. Magill, MD
}

"Funny, but I have found myself grieving longer than I expected," Debra said on the telephone from New York. Although I hadn't known it before, I realized that was the real reason I called her several weeks after her aunt Jeanine, my patient, died. I, too, was having a hard time letting go of Jeanine. I thought I called to see how Debra was doing. I wanted to hear how she experienced the last few days of Jeanine's life, when Debra had flown to be with her aunt at the end of a long illness. "I got there in time for her to recognize me," she said. "I didn't mind the morphine. She moaned every time they moved her." Then she reminisced a while: "She was always there for me, so I was glad to be there for her when I could. She was the only one who told me I could be an actress in New York, and now I am. She was a famous actress in her own day, you know. I still remember standing ovations she got in Los Angeles for Soutb Pacific."

No, I didn't know, I thought, but that explains a lot.

As we talked, my mind drifted back to images of Jeanine. I remembered the first time I'd met her, something I now understand as the opening act: Jeanine walked slowly down the hallway of my office, she wielded a cane like a weapon, gasped for breath. A pleural effusion turned out to be hydrothorax secondary to cirrhosis. Good Mormon lady, she never drank. Extensive workup did not reveal a cause.

She had moved from California some months earlier. Not seen a physician since arrival despite her illness. No family around. Lived alone. Drove herself. Drove everyone else away with her cane and crankiness.

Submitted, revised, 15 June 1998.

From the Department of Family and Preventive Medicine, University of Utah School of Medicine, Salt Lake City. Address reprint requests to Michael K. Magill, MD, Department of Family and Preventive Medicine, University of Utah School of Medicine, 50 North Medical Drive - 1C26SOM, Salt Lake City, UT 84132.
I found other things-esophageal varices, diabetes, hypertension, renal insufficiency, the usual. We survived them together as best we could. I made medication adjustments from time to time, none of which seemed to make a bit of difference to her metabolism. At one point she came to see me saying she had felt depressed for weeks. I gave her medicine for that, but she quit taking it and got better on her own.

Mostly I searched for ways Jeanine could let me be her doctor, not something that came easily to either of us. She didn't accept help lightly. Or dependency. Or illness. She yelled at my office staff, complained when I was late. She had her car in the parking lot ready to go, she said. She threatened to drive to California but said her family there had never cared about her, and in her condition it was too long a trip.

I'd sit and look her in the eye, let her cry when she could, tell her it was okay for her to get as mad at me as she wanted, I'd still care about her-just please don't hit me with that cane. She'd laugh and politely point out what a pain I was before composing herself and sailing out of the office.

A couple times in as many years she entered the hospital for diuresis or treatment of hepatic encephalopathy. Scared by one of these events, she finally let me send home health aides to keep her medicines straight. She even let Meals on Wheels in her apartment door. She told me Debra was the only relative I could call, so I did and told her Jeanine was getting sicker.

Eventually Jeanine could not get out of bed without help. The nurses visited twice a day, and she went to the hospital more often for weakness or bleeding or confusion. Each time she complained, and I couldn't have agreed with her more. "Why do I have to stay in the emergency department so long?" "Why do those students and residents come to ask me the same questions over and over again just like they did last time I was admitted?" "Why do they want to keep sticking needles in my belly?" "My chest?" "Who are all these peo- 
ple?" "I want to go home." "Leave me alone!"

I'd go into her room, sit on the bed, and ask her when she was going to give birth to what looked like a 10-month baby. Old maid, she'd try to lift her head, but then laugh and ask where they had found such an obnoxious doctor.

Finally, she couldn't care for herself, even with help from the visiting nurses, who had virtually adopted her. The hospital staff told her she had to go to a nursing home. "What else can we do with you?" they asked. But she refused their pleas, angry. So I told her I, too, was scared to let her go home; I wanted her to get enough care so she'd be safe, to go to a nursing home, and then if she got her strength back, she could go home. She said, "All right then, I'll go there, but home soon." Of course she never went home, just kept bleeding, became obtunded, and died.

Since then, I had found myself scratching an itch that wasn't there, missing her grit. As I talked with her niece, I realized that Jeanine had given us a life well performed, a character deliberate and solid. Looking back, I think my role was to accept her on her own terms, let her know I saw her enthusiasm for opposition and would not be driven away by it. I simply told her what I saw: a swinging cane, a dyspneic, pregnant-looking old lady. I also held her hand when science failed to heal or soothe. In reply, she confessed her solace with laughter, trust, and even tears. What greater gifts can a patient offer her doctor?

Finishing the telephone call, ready now, I said good-bye, cradled the receiver, and stood gratefully in silence. 